\title{
Effects of feeding live yeast at 2 dosages on performance and feeding behavior of dairy cows under heat stress
}

\author{
M. C. Perdomo, ๑ R. S. Marsola, M. G. Favoreto, $\bullet$ A. Adesogan, $\bullet$ C. R. Staples, $\odot$ and J. E. P. Santos* $\bullet$ \\ Department of Animal Sciences, University of Florida, Gainesville 32611
}

\section{ABSTRACT}

The objectives were to evaluate the effects of feeding different amounts of supplemental live yeast (LY) on performance and digestion of cows under heat stress. Sixty Holstein cows, 27 multiparous and 33 primiparous, were blocked by parity and milk yield in the first $20 \mathrm{~d}$ in milk (DIM) and randomly assigned to receive $0,0.5$, or $1.0 \mathrm{~g} / \mathrm{d}$ of $\mathrm{LY}$, resulting in daily intakes of 0 , 14.2 , and 37.6 billion cells, respectively, of Saccharomyces cerevisiae strain CNCM I-1077 from 30 to 107 DIM. Cows were milked twice daily, dry matter intake (DMI) and milk yield were measured daily, and milk components, body weight, and body condition were measured weekly. Blood was sampled weekly and plasma analyzed for concentrations of glucose, fatty acids, urea N, haptoglobin, serum amyloid A, and acid-soluble protein. Digestibility of nutrients was measured in the last 2 wk of the experiment. Ruminal fluid was collected on 2 consecutive days $6 \mathrm{~h}$ after the morning feeding for measurements of $\mathrm{pH}$, concentrations of short chain fatty acids, and $\mathrm{NH}_{3}-\mathrm{N}$. Feeding behavior was observed for $48 \mathrm{~h}$ on experiment $\mathrm{d} 21$ and 63 . The mean ambient temperature was $26.8^{\circ} \mathrm{C}$, humidity was $83.2 \%$, and the temperature and humidity index ranged from 73 to 81 . Treatment did not affect rectal temperature $(38.9 \pm$ $0.04^{\circ} \mathrm{C}$ ) or DMI but increased yield of energy-corrected milk (ECM; 35.2 vs. 36.1 vs. $37.2 \mathrm{~kg} / \mathrm{d}$ for $0,0.5$, and $1.0 \mathrm{~g} / \mathrm{d}$, respectively) and efficiency of conversion of DM into ECM (1.70, 1.79, and 1.83 for $0,0.5$, and 1 $\mathrm{g} / \mathrm{d}$, respectively). Feeding LY increased digestibility of crude protein (65.1 vs. 68.8 vs. $70.4 \%$ ) and neutral detergent fiber (NDF; 47.5 vs. 49.2 vs. $55.2 \%$ ), and concentration of acetate (64.7 vs. 69.1 vs. $72.2 \mathrm{mM}$ ), which resulted in increased concentration of total short chain fatty acids in ruminal fluid (110.3 vs. 117.7 vs. $121.4 \mathrm{mM}$ ). Mean ruminal $\mathrm{pH}$ increased (5.99 vs. 6.03 vs. 6.26), and proportion of cows with $\mathrm{pH}<5.8$ de-

Received July 20, 2019.

Accepted September 9, 2019.

*Corresponding author: jepsantos@ufl.edu creased linearly (42.9 vs. 34.9 vs. $7.7 \%$ ) with increasing inclusion of LY. Concentrations of acute-phase proteins decreased with increasing amount of LY. Some aspects of feeding behavior were altered by LY, and meal size reduced quadratically $(3.2,3.5$, and $2.9 \mathrm{~kg}$ of DM, respectively), whereas interval between rumination bouts tended to reduce linearly $(122,96.5$, and $90.7 \mathrm{~min}$, respectively) with increasing dose of LY. Chewing time per kilogram of NDF tended to increase linearly (71.6, 71.3 , and $81.6 \mathrm{~min} / \mathrm{kg}$, respectively) with increasing dose of LY. The estimated net energy for lactation of the diet increased $5.2 \%$, from $1.72 \mathrm{Mcal} / \mathrm{kg}$ of DM for $0 \mathrm{~g}$ of LY to $1.81 \mathrm{Mcal} / \mathrm{kg}$ for $1 \mathrm{~g}$ of LY. Feeding $1 \mathrm{~g}$ of $\mathrm{LY} / \mathrm{d}$ to cows under heat stress increased yield of ECM and efficiency of feed conversion into ECM, improved diet digestibility, and increased ruminal fluid $\mathrm{pH}$; these responses might be related either to direct effects of LY on ruminal microbial activity or to changes in feeding behavior that improved digestion of cows in heat stress. Key words: dairy cow, heat stress, live yeast, lactation

\section{INTRODUCTION}

Saccharomyces cerevisiae is a single-celled fungus capable of fermenting carbohydrates that is commonly used as a feed additive in diets of ruminant livestock. Saccharomyces cerevisiae is typically fed to dairy cattle either as a live yeast (LY) or as a yeast culture (YC) containing live and dead cells and the products of fermentation, or a combination of both, with the aim of altering ruminal fermentation in an attempt to improve nutrient digestion and $\mathrm{N}$ utilization, and to stabilize ruminal $\mathrm{pH}$, reducing the risk of ruminal acidosis, and improve animal performance (Desnoyers et al., 2009). Experiments have documented that provision of LY or YC has potential to modify dairy cow feeding behavior patterns (Bach et al., 2007; DeVries and Chevaux, 2014; Dias et al., 2018a).

The proposed mechanisms of action of $S$. cerevisiae are multiple. Live $S$. cerevisiae scavenges ruminal oxygen (Newbold et al., 1996), which reduces ruminal redox potential, favoring the activity of cellulolytic bacteria and lactate-utilizing bacteria (Marden et 
al., 2008). In fact, Jiang et al. (2017) observed that supplementing LY to the diet of dairy cows increased the relative abundance of cellulolytic, amylolytic, and lactate-utilizing microorganisms, whereas supplementing YC increased populations only of amylolytic and lactate-utilizing microorganisms. Bach et al. (2007) suggested that one of the mechanisms by which LY increases the ruminal $\mathrm{pH}$ and reduces the risk of subacute ruminal acidosis is by altering patterns of feed intake and feeding behavior, because yeast-supplemented cows increased meal frequency, which is thought to alleviate the acid load in the rumen.

One of the many challenges of producing milk in hot, humid climates is the decline in DMI and milk yield when cows are exposed to heat stress. In acute heat stress models, approximately $50 \%$ of this reduction in milk production has been attributed to a decline in voluntary DMI (Wheelock et al., 2010). Nutrient intake during summer becomes the most limiting factor for optimum production; therefore, a logical strategy to improve performance of cows under heat stress is to minimize the reduction in DMI or to improve nutrient utilization by increasing diet digestion. Reducing dietary fiber from forage and increasing the amount of concentrates is a strategy to encourage feed intake, in part because of the reduced heat increment (Reynolds et al., 1991); however, low-forage diets and heat stress are known risk factors for subacute ruminal acidosis (Nocek, 1997).

One of the strategies proposed to improve performance during periods of heat stress is the use of rumen modifiers that either stimulate intake or improve nutrient digestion. Feeding LY or YC to cows under heat stress has been shown to improve lactation performance (Bruno et al., 2009; Moallem et al., 2009; Salvati et al., 2015). Cows under heat stress are more prone to low ruminal fluid $\mathrm{pH}$ (Mishra et al., 1970), and, therefore, supplementing diets with compounds that attenuate reductions in ruminal $\mathrm{pH}$ might benefit digestion and performance of cows. Nevertheless, only a few experiments have evaluated the effects of feeding LY to cows under heat stress conditions (Moallem et al., 2009; Salvati et al., 2015).

We hypothesized that feeding incremental amounts of a rumen-specific LY would improve nutrient digestion and rumen function, which would result in increased yields of milk and milk components of early-lactation dairy cows exposed to heat stress. Thus, our objectives were to evaluate the effects of feeding increasing amounts of a rumen-specific strain of LY to earlylactation dairy cows during heat stress on measures of rumen function, nutrient digestion, feeding behavior, and lactation performance.

\section{MATERIALS AND METHODS}

All experimental cows were managed according to the guidelines approved by the University of Florida Institute of Food and Agricultural Sciences Animal Research Committee.

\section{Animals, Housing, and Feeding}

Lactating Holstein cows, 33 primiparous and 27 multiparous cows from the University of Florida Dairy Unit, were enrolled in the experiment. Cows were housed in a single freestall barn with sand-bedded stalls, and each cow was randomly assigned to an individual feeding gate (Calan Broadbent feeding system, American Calan Inc., Northwood, NH) for measurements of individual cow feed intake.

The experiment was conducted from May to September, to coincide with the hottest months of the year, and only cows calving during the months of April to June were enrolled. The experimental pen was equipped with 2 rows of fans ( 1 fan per 6 linear $\mathrm{m}$ ), one facing the feed lane immediately above the feedbunk and the other immediately above the beds. Fans were equipped with low-pressure water nozzles, and both fans and nozzles were activated once ambient temperature reached $21.1^{\circ} \mathrm{C}$.

All cows received the same TMR (Tables 1 and 2) fed twice daily, at $0800 \mathrm{~h}$ immediately after cows were milked and again at $1230 \mathrm{~h}$. The TMR was formulated using the NRC (2001) to meet the caloric and MP requirements of early-lactation Holstein cows weighing $610 \mathrm{~kg}$, producing $38 \mathrm{~kg}$ of milk with $3.5 \%$ fat and $3.0 \%$ true protein, and consuming $21 \mathrm{~kg}$ of $\mathrm{DM} / \mathrm{d}$. The grain mix portion of the diet included only dry ingredients and was mixed weekly, stored, and then mixed with forage and wet feeds daily before each feeding. The amount of feed offered to individual cows was adjusted daily to result in at least $5 \%$ orts, and refusals were weighed once daily at $0700 \mathrm{~h}$, before the morning feeding.

Once weekly, forages, brewers grains, the grain mix, and TMR were sampled and dried at $55^{\circ} \mathrm{C}$ for $48 \mathrm{~h}$. Moisture disappearance was recorded, and samples were then stored at $5^{\circ} \mathrm{C}$ for later analyses as monthly composites.

\section{Treatments}

Weekly cohorts of cows at 20 DIM were moved to the experimental pen for a 10-d pretreatment period and to acclimate to individual feeding gates. During the pretreatment period, cows were fed the same TMR used in 
Table 1. Ingredient composition of the TMR and grain mixture

\begin{tabular}{lr}
\hline Ingredient & $\%$ DM \\
\hline Composition of TMR & \\
Corn silage & 41.4 \\
Alfalfa hay & 10.2 \\
Brewers grains, wet & 5.2 \\
Grain mixture & 43.2 \\
Composition of the grain mixture & \\
Corn grain, finely ground & 42.8 \\
Corn distillers grains, dry & 7.2 \\
Pelleted citrus pulp, dry & 15.9 \\
Soybean meal, solvent extracted & 19.2 \\
Soybean meal, expeller ${ }^{1}$ & 4.9 \\
Prilled saturated free fatty acids ${ }^{2}$ & 1.4 \\
Premix & 8.6 \\
\hline
\end{tabular}

${ }^{1}$ SoyPLUS, West Central, Ralston, IA.

${ }^{2}$ Energy Booster 100, Milk Specialties Global, Dundee, IL.

${ }^{3}$ Contains (DM basis) $30.8 \%$ porcine blood meal, $30.5 \%$ sodium bicarbonate, $12.0 \%$ dicalcium phosphate, $6.0 \%$ magnesium oxide, $4.8 \%$ magnesium sulfate heptahydrate, $2.9 \%$ sodium chloride, $0.12 \%$ manganese sulfate monohydrate, $0.06 \%$ zinc sulfate, $2.9 \%$, MetaSmart (Adisseo, Atlanta, GA), 0.25\% Zinpro 4-Plex (Zinpro Co., Eden Prairie, MN), 0.45\% Sel-Plex 2000 (Alltech Biotechnology, Nicholasville, KY), $0.25 \%$ Rumensin 80 (Elanco Animal Health, Greenfield, IN), and vitamin and iodine premix. Each $\mathrm{kg}$ contains $28.5 \% \mathrm{CP}, 6.3 \% \mathrm{Ca}, 1.2 \% \mathrm{P}, 3.9 \%$ $\mathrm{Mg}, 10.5 \% \mathrm{Na}, 3.1 \% \mathrm{Cl}, 587 \mathrm{mg}$ of $\mathrm{Zn}, 124 \mathrm{mg}$ of $\mathrm{Cu}, 654 \mathrm{mg}$ of $\mathrm{Mn}$, $9.6 \mathrm{mg}$ of Se, $25 \mathrm{mg}$ of Co, $13 \mathrm{mg}$ of I, 131,000 IU of vitamin A, 36,000 IU of vitamin D, 1,200 IU of vitamin E, and $470 \mathrm{mg}$ of monensin.

the experiment. The experiment was conducted for 11 wk, from 30 to 107 DIM. Cows were randomly assigned at 30 DIM to receive $0 \mathrm{~g} / \mathrm{d}$ (11 primiparous and 9 multiparous), $0.5 \mathrm{~g} / \mathrm{d}$ (11 primiparous and 9 multiparous), or $1.0 \mathrm{~g} / \mathrm{d}$ of LY (11 primiparous and 9 multiparous).
The LY used was S. cerevisiae strain CNCM I-1077 (Levucell SC20, Lallemand Animal Nutrition, Milwaukee, WI), containing a minimum of 20 billion cells per gram according to the manufacturer.

The LY was carefully mixed with corn meal to result in 2 mixtures containing either 0.5 or $1 \mathrm{~g}$ of $\mathrm{LY} / 200 \mathrm{~g}$ of corn meal. Diets were top-dressed concurrent with the morning feeding with $200 \mathrm{~g}$ of corn meal only (control, $0 \mathrm{~g} / \mathrm{d}$ ) or with $200 \mathrm{~g}$ of the respective corn meal + LY mixture to provide 0.5 or $1 \mathrm{~g} / \mathrm{d}$ of LY. Multiple samples of the mixtures containing $0,0.5$, and $1 \mathrm{~g}$ of LY/200 $\mathrm{g}$ of corn meal were shipped unidentified to the quality control laboratory of Lallemand Animal Nutrition for analysis of S. cerevisiae count (cfu). Samples were plated in Sabouraud dextrose agar medium with added chloramphenicol for quantification, and identification of strain CNCM I-1077 was performed via PCR. Analyses were performed before starting the experiment, to ensure that the correct numbers of viable yeast cells were present in the top-dressed mixtures.

\section{Measurements of Ambient, Vaginal, and Rectal Temperatures, and Respiration Rate}

Ambient temperature $\left({ }^{\circ} \mathrm{C}\right)$ and relative humidity (\%) were evaluated every 15 min throughout the experiment, utilizing electronic data loggers (HOBO; Onset Computer, Bourne, MA). The corresponding temperature-humidity index (THI) was calculated using ambient temperature and relative humidity according to the

Table 2. Nutrient composition of the dietary ingredients and TMR (DM basis; mean \pm SD of 5 composite samples)

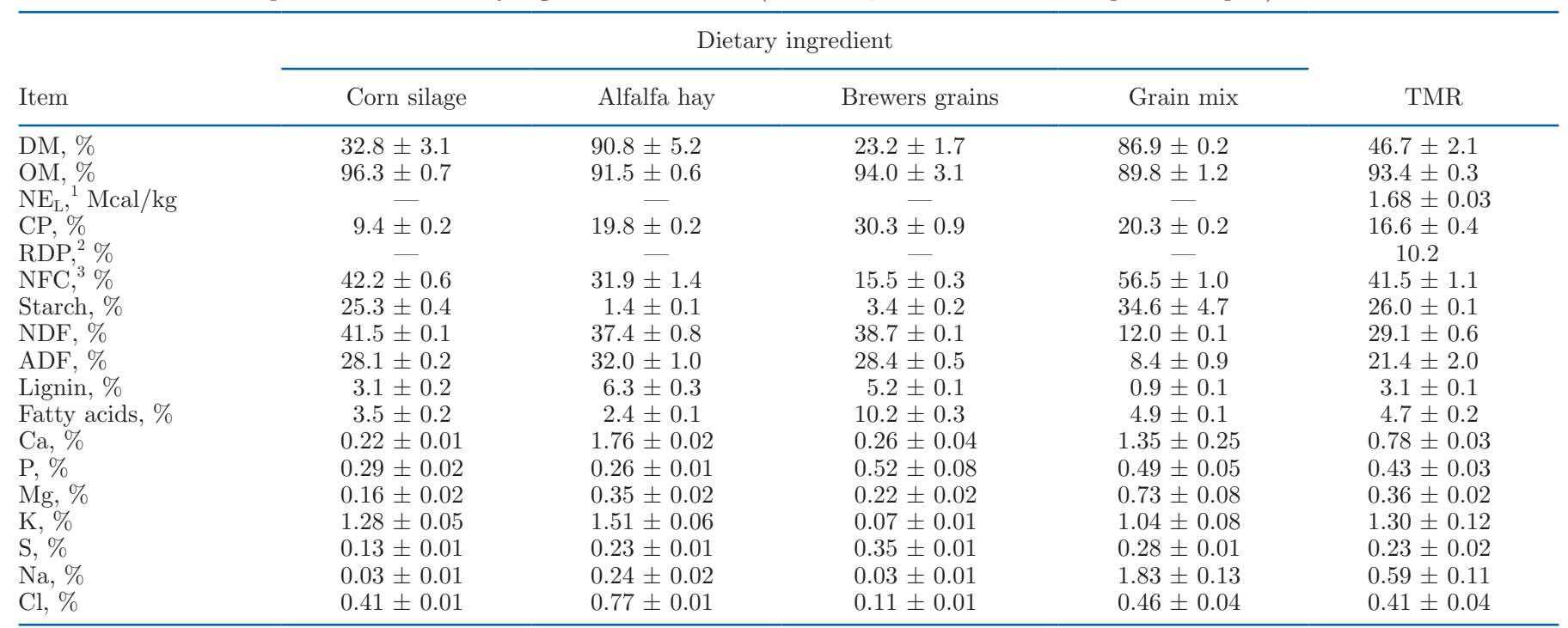

${ }^{1}$ Net energy for lactation calculated using NRC (2001) and adjusted for the observed mean DMI in the experiment (20.5 kg/d).

${ }^{2}$ Rumen-degradable protein for a cow consuming $20.5 \mathrm{~kg}$ of DM/d according to NRC (2001).

${ }^{3}$ Nonfibrous carbohydrates calculated as $\mathrm{OM}-(\mathrm{NDF}-\mathrm{NDFICP}+\mathrm{CP}+$ fatty acids). NDFICP $=\mathrm{CP}$ insoluble in NDF solution. 
following formula: $\mathrm{THI}=[(1.8 \times$ ambient temperature $)$ $+32]-[0.55-(0.0055 \times$ relative humidity $)] \times[(1.8 \times$ ambient temperature) -26$]$.

Vaginal temperature was measured continuously during 3 consecutive days, when cows were on experiment d 28 and 68, to characterize the diurnal pattern of body temperature. Measurements were recorded every 15 min using electronic data loggers (HOBO; Onset Computer) attached to blank intravaginal inserts (EAZI-BREED CIDR insert; Zoetis, Madison, NJ) devoid of progesterone. Measurements of vaginal temperature were averaged into hourly means within each day, for statistical analyses. Rectal temperatures were also measured using an electronic thermometer (M750 thermometer; GLA Agricultural Electronics, San Luis Obispo, CA) twice daily, at 0900 and $1600 \mathrm{~h}$, during 5 consecutive days starting on experiment d 63. Respiration rate of every cow was measured once weekly by counting the number of breaths during a 2-min period, at 0900 and $1600 \mathrm{~h}$.

\section{Measurements of Milk and Milk Components}

Cows were milked twice daily at approximately 0730 and $1900 \mathrm{~h}$, and individual yield of milk was recorded by the Afikim milking system (AfiFlo milk meters; SAE Afikim, Israel). Individual milk samples were also collected once weekly from consecutive morning and afternoon milkings and analyzed by DHI laboratory at Southeast Milk Inc. (Belleview, FL) for SCC, fat concentration, true protein, and lactose using a Bentley 2000 NIR analyzer (Bentley Instruments, Chaska, MN). Final concentrations of milk components were calculated after adjustment for milk production in the respective milkings when samples were collected.

\section{Body Weight, Body Condition Score, and Measurement of Energy Balance}

Cows were weighed immediately after the morning milking, twice during the pretreatment period, and 1 $\mathrm{d} /$ wk, after the morning and evening milking, during the 11-wk experiment. Body condition was scored by the same person, using a 1 to 5 scale (Ferguson et al., 1994), twice during the pretreatment period and once weekly thereafter. Energy balance was calculated using NRC (2001) equations for $\mathrm{NE}_{\mathrm{L}}$ requirements for maintenance according to $\mathrm{BW}$ of cows $\left(0.08 \times \mathrm{BW}^{0.75}\right)$, $\mathrm{NE}_{\mathrm{L}}$ for milk synthesis according to concentrations of fat, protein, and lactose in milk $[(0.0929 \times$ fat $\%)+$ $(0.0563 \times$ protein $\%)+(0.0395 \times$ lactose $\%)]$, and $\mathrm{NE}_{\mathrm{L}}$ concentration of the TMR. Fat-corrected milk at 3.5\% fat $[(0.4324 \times$ milk yield $)+(16.218 \times$ milk fat yield $)]$ and $\operatorname{ECM}[(0.3246 \times$ milk yield $)+(12.86 \times$ fat yield $)$ $+(7.04 \times$ protein yield $)]$ were also calculated according to NRC (2001).

The $\mathrm{NE}_{\mathrm{L}}$ content of diets was estimated based on the $\mathrm{NE}_{\mathrm{L}}$ needs for maintenance of cows, the net energy (NE) secreted in milk, changes in BW, and the DMI observed. For the purpose of calculations in this experiment, we assumed that each $\mathrm{kg}$ of $\mathrm{BW}$ change was equivalent to $5.0 \mathrm{Mcal}$ of $\mathrm{NE}_{\mathrm{L}}$, compatible with the value suggested by NRC (2001) for a cow with BCS of 3.00 and either losing $(4.68 \mathrm{Mcal} / \mathrm{kg}$ ) or gaining (5.34 $\mathrm{Mcal} / \mathrm{kg}) 1 \mathrm{~kg}$ of live BW.

\section{Blood Sampling and Analyses}

Approximately $8 \mathrm{~mL}$ of blood was sampled once weekly, $4 \mathrm{~h}$ after the morning feeding, by puncture of the coccygeal blood vessels, into tubes containing $\mathrm{K}_{2}$ EDTA (Vacutainer; Becton Dickinson, Franklin Lakes, NJ). Tubes were placed on ice and transported to the laboratory within $3 \mathrm{~h}$, centrifuged at $3,000 \times g$ for 15 min at $4^{\circ} \mathrm{C}$, and plasma was frozen in aliquots at $-25^{\circ} \mathrm{C}$ for later analyses.

Plasma samples were analyzed for concentrations of fatty acids (Johnson and Peters, 1993) using a commercial kit (NEFA C, Wako Chemicals USA Inc., Richmond, VA). The concentrations of glucose (Bran and Luebbe Industrial Method 339-19; Gochman and Schmitz, 1972) and urea N (Bran and Luebbe Industrial Method 339-01; Marsh et al., 1965) in plasma were analyzed using an autoanalyzer (Bran Luebbe 199-A001-01 Technicon S.C. Colorimeter Autoanalyzer II, Technicon Instruments Corp., Tarrytown, NY). Plasma haptoglobin concentrations were determined according to the method of Makimura and Suzuki (1982). Acid-soluble protein was extracted from plasma with a solution of $0.6 M$ perchloric acid and analyzed with bicinchoninic acid kit (Sigma-Aldrich, Saint Louis, MO; kit number BCA1). Serum amyloid A concentration in plasma was measured using an enzyme immune assay (Tri-Delta Diagnostics Inc., Morris Plains, NJ; catalog number TP-802) according to Gozho et al. (2005).

\section{Apparent Total-Tract Digestibility, Analyses of Nutrients, and Ruminal Fluid Composition}

In the last $12 \mathrm{~d}$ of the experiment, cows were dosed orally twice daily with a gelatin capsule containing $10 \mathrm{~g}$ of $\mathrm{Cr}_{2} \mathrm{O}_{3}(20 \mathrm{~g} /$ cow per day $)$, which was used as an indigestible marker to estimate total-tract apparent digestibility of DM, OM, CP, ADF, and NDF via the marker ratio technique (Schneider and Flatt, 1975). During the last $5 \mathrm{~d}$, TMR, orts from individual cows, and fecal 
samples were collected twice daily after the morning and afternoon milkings, at 12-h intervals. Samples of feces, TMR, and individual orts were composited for the 5-d collection period for individual cows and dried in a forced-air oven at $55^{\circ} \mathrm{C}$ for $96 \mathrm{~h}$. Moisture loss was recorded, and samples were ground to pass a $1-\mathrm{mm}$ screen of a Wiley mill (Thomas Scientific, Swedesboro, $\mathrm{NJ})$. Samples were then analyzed for $\mathrm{Cr}$ in feces and orts via atomic absorption spectrophotometry (Williams et al., 1962). Samples of TMR, orts, and feces were also analyzed for their content of DM $\left(105^{\circ} \mathrm{C}\right.$ for $\left.12 \mathrm{~h}\right)$ and $\mathrm{OM}\left(512^{\circ} \mathrm{C}\right.$ for $\left.8 \mathrm{~h}\right)$, sequential analysis of NDF using a heat-stable $\alpha$-amylase and ADF (Van Soest et al., 1991) with the Ankom Fiber Analyzer system (Ankom Technology, Macedon, NY), and N using an automated quantitative combustion digestion method (Elementar Analysensysteme, Elementar Americas Inc., Mt. Laurel, NJ).

Samples of dietary ingredients and TMR collected weekly throughout the experiment, dried at $55^{\circ} \mathrm{C}$ and ground to pass a 1-mm screen, were composited monthly for analysis of DM, OM, ADF, NDF, and N, as described previously. Samples were also analyzed for starch (Vidal et al., 2009), ADL (Hindrichsen et al., 2006), and total fatty acids (Sukhija and Palmquist, 1988). The mineral content was analyzed at the Dairyland Laboratory (Arcadia, WI) using an inductively coupled plasma mass spectrometer (Thermo JarrellAsh, Franklin, MA). The caloric density of the diet (Mcal of $\mathrm{NE}_{\mathrm{L}} / \mathrm{kg}$ ) was calculated according to the nutrient content of the ingredients and adjusted for the observed mean DMI of all cows during the experiment using NRC (2001) software.

On the last $2 \mathrm{~d}$ of the experiment, rumenocentisis was performed by puncture of the left ventral region of the abdomen using a disposable sterile needle (18 gauge, 12 $\mathrm{cm}$ ). Ruminal fluid was collected from all cows between 7 and $8 \mathrm{~h}$ after the morning feeding. Approximately 10 $\mathrm{mL}$ of ruminal fluid was collected, the $\mathrm{pH}$ measured immediately, and then divided into 2 aliquots. One aliquot was immediately frozen in liquid $\mathrm{N}_{2}$ and then transferred to a $-80^{\circ} \mathrm{C}$ freezer for later analyses. A second aliquot was acidified with $50 \%$ sulfuric acid to a $\mathrm{pH}$ below 2 and then centrifuged at $5,400 \times g$ for $20 \mathrm{~min}$. The supernatant was collected and frozen at $-20^{\circ} \mathrm{C}$ until further analysis of short-chain fatty acids (SCFA) and $\mathrm{NH}_{3}-\mathrm{N}$ concentrations. Later, the fluid was thawed, centrifuged at $4^{\circ} \mathrm{C}$ and $21,500 \times g$ for 20 min, and the supernatant analyzed for concentrations of lactate and SCFA using the method of Canale et al. (1984) with a high-performance liquid chromatograph (Merck Hitachi, Elite Lachrom HTA, Tokyo, Japan) coupled to a UV detector (Merck Hitachi L-2400) set at $210 \mathrm{~nm}$ and a Bio-Rad Aminex HPX-87H column (Bio-Rad Laboratories, Hercules, CA) with $0.015 M$ sulfuric acid mobile phase and a flow rate of $0.7 \mathrm{~mL} /$ min at $45^{\circ} \mathrm{C}$, and crotonic acid as the internal standard. Ammonia $\mathrm{N}$ was determined using a Technicon autoanalyzer (Technicon, Tarrytown, NY) according to the method of Noel and Hambleton (1976) for colorimetric $\mathrm{N}$ quantification. The results of both samples were averaged into a single mean value per cow for statistical analyses.

\section{Feeding Behavior}

The feeding behavior of a subset of 39 cows $(0 \mathrm{~g} / \mathrm{d}$ $=14$ cows; $0.5 \mathrm{~g} / \mathrm{d}=13$ cows; $1 \mathrm{~g} / \mathrm{d}=12$ cows) was evaluated for $48 \mathrm{~h}$ on 2 consecutive days when cows averaged $21($ mean $=21$, median $=21)$ and 63 (mean $=63$, median $=65) \mathrm{d}$ in the experiment. During those $4 \mathrm{~d}$ of feeding behavior observation, cows were fed once daily at $0800 \mathrm{~h}$. Amounts were offered to allow 3 to $5 \%$ orts on those days.

Details of the feeding behavior observation methods have been reported elsewhere (Maltz et al., 2013; Dias et al., 2018a). Briefly, cows were observed every $5 \mathrm{~min}$, starting immediately after the morning milking and ending immediately before the morning milking of the subsequent day. Cows were not observed during milking. The location and activity of each cow was recorded as ruminating standing, ruminating lying in the stall, standing only, lying only, eating, and drinking. Each observation was assumed to last $5 \mathrm{~min}$, which was the interval between observations. Chewing was considered as the summation of rumination and eating. The number of eating, lying, and chewing bouts, duration of each meal, interval between meals, total time eating, total time ruminating only, and total time chewing were calculated. A bout for an activity was considered if it lasted at least 2 consecutive observations.

The amount of feed consumed was measured every $2 \mathrm{~h}$, and the amount that disappeared from the bunk and was consumed by each cow was calculated and expressed either as $\mathrm{kg}$ or as percentage of the total daily DMI for those days. Approximately $200 \mathrm{~g}$ of the diet was sampled from the bunk of each cow at hourly intervals starting immediately before cows began eating and ending $24 \mathrm{~h}$ later, when cows were moved to the parlor to be milked. Samples were screened immediately after collection to determine particle size distribution of the diet of each cow, using the 4 -sieve $(<1.18 \mathrm{~mm}, 1.18$ to $8.0 \mathrm{~mm}, 8.0$ to $19.0 \mathrm{~mm}$, and $>19.0 \mathrm{~mm}$ ) Penn State Particle Separator. The DM and NDF concentrations of the diet offered and refused by each cow during $24 \mathrm{~h}$ were analyzed, and the NDF consumed was computed 
as total NDF, as well as using NDF with particles $\geq 1.18 \mathrm{~mm}$ or $\geq 8.0 \mathrm{~mm}$ as cutoff points for physically effective NDF (peNDF) offered and refused.

\section{Experimental Design and Statistical Analyses}

After a pretreatment period of $10 \mathrm{~d}$ in which cows were fed a common diet, weekly cohorts were blocked by parity (primiparous or multiparous) and pretreatment milk yield and, within block, randomly assigned to 1 of the 3 treatments. Data collected in the last 7 $\mathrm{d}$ of the pretreatment period were used for covariate adjustment during statistical analyses. The number of experimental units was initially calculated for a randomized block design with an expected difference in milk yield between the lowest and highest treatment of $1.5 \mathrm{~kg} / \mathrm{d}$ and standard deviation of $2.5 \mathrm{~kg}(\alpha=0.05$; $\beta=0.80)$. For that, a total of 57 cows (19/treatment) were necessary.

Continuous data were analyzed by ANOVA using the MIXED procedure of SAS version 9.4 (SAS/STAT, SAS Institute Inc., Cary, NC), and binary data were analyzed using logistic regression with the GLIMMIX procedure of SAS. For continuous data, normality of residuals and homogeneity of variance were examined for each continuous dependent variable analyzed after fitting the model. Responses that violated the assumptions of normality were subjected to power transformation using PROC TRANSREG in SAS. The least squares means and standard error of the mean were back-transformed for presentation of results according to Jørgensen and Pedersen (1998).

Outcomes with repeated measurements over time within the same experimental unit were analyzed with models that included the fixed effects of treatment $(0,0.5$, or $1 \mathrm{~g} / \mathrm{d}$ of LY), parity (primiparous or multiparous), week of measurement (1 to 11), interaction between treatment and parity, interaction between treatment and week, and pretreatment covariate, and random effects of block and cow nested within treatment. For respiration rate and rectal temperature, the effect of period of the day (morning and or afternoon) and interaction between treatment and period were also included in the models. For vaginal temperature, the effect of hour of the day and interaction between treatment and hour were further included. Data on feeding behavior, which included 2 consecutive days of observation early (d 21 and 22) and late (d 63 and 64) in the experiment were averaged per period and analyzed with the fixed effects of treatment, parity, behavior period (21 vs. $63 \mathrm{~d})$, and interactions between treatment and parity, treatment and behavior period, and treatment and parity and behavior period, and the random effects of block and cow nested within treatment. The cova- riance structure with the lowest Akaike's information criterion from the fit statistics parameters was chosen for each analysis performed.

Outcomes with a single measurement within experimental unit (ruminal fluid parameters and digestibility coefficients) were analyzed with the fixed effects of treatment, parity, and interaction between treatment and parity, and the random effect of block.

Preplanned orthogonal polynomial comparisons were performed in all statistical analyses to evaluate linear and quadratic responses to the amount of LY fed on the responses analyzed. Least squares means and proportions are reported. Treatment differences with $P \leq$ 0.05 were considered significant, whereas tendencies to differences were accepted if $0.05<P<0.10$.

\section{RESULTS}

No S. cerevisiae strain CNCM I-1077 was detected in the top-dress mixture for cows fed $0 \mathrm{~g} / \mathrm{d}$ of LY. Twelve sample analyses of top-dressed mixtures of treatment $0.5 \mathrm{~g} / \mathrm{d}$ of LY contained, respectively, mean $( \pm \mathrm{SD})$ and median concentrations of $0.71( \pm 0.14) \times 10^{8} \mathrm{cfu} / \mathrm{g}$ and $0.66 \times 10^{8} \mathrm{cfu} / \mathrm{g}$. The 12 samples analyzed of treatment $1 \mathrm{~g} / \mathrm{d}$ of LY contained mean $1.88( \pm 0.33) \times 10^{8}$ $\mathrm{cfu} / \mathrm{g}$ and median $1.80 \times 10^{8} \mathrm{cfu} / \mathrm{g}$. These concentrations would result in estimated daily intakes of $0,14.2$ $\left(1.42 \times 10^{10}\right)$, and $37.6\left(3.76 \times 10^{10}\right)$ billion cells of $S$. cerevisiae strain CNCM I-1077 per cow in 0, 0.5, and 1 $\mathrm{g} / \mathrm{d}$, respectively, of LY in the $200 \mathrm{~g}$ of top-dress offered per cow daily. Therefore, cows fed 0.5 and $1 \mathrm{~g}$ of LY received a daily dose of $S$. cerevisiae 42 and $88 \%$ greater, respectively, than the minimum expected based on the concentration of cells described in the product.

\section{Environmental and Rectal Temperature and Respiration Rate}

Cows were exposed to heat stress throughout the experiment from June to September, and the mean daily THI in the experimental barn was consistently greater than 75 (Supplemental Figure S1A; https://doi .org/10.3168/jds.2019-17303). A diurnal pattern was observed: THI was lowest in the morning, between 0600 and $0700 \mathrm{~h}$, began to rise at approximately $0800 \mathrm{~h}$, and reached a peak at approximately $1300 \mathrm{~h}$, after which it remained above 77 until $1900 \mathrm{~h}$ and, finally, began to decline (Supplemental Figure S1B; https://doi.org/10 .3168/jds.2019-17303). The diurnal pattern of vaginal temperature was similar to the pattern of THI (Supplemental Figure S1C; https://doi.org/10.3168/jds.2019 -17303). Vaginal temperature reached $39.1^{\circ} \mathrm{C}$ at $1400 \mathrm{~h}$ and remained elevated until $2100 \mathrm{~h}$, when it began to decline, to reach a nadir of $38.6^{\circ} \mathrm{C}$ at $0100 \mathrm{~h}$. No treat- 
Table 3. Effects on body temperature and respiration rate of feeding increasing amounts of live yeast to cows exposed to heat stress; values represent LSM \pm SEM

\begin{tabular}{|c|c|c|c|c|c|c|}
\hline \multirow[b]{2}{*}{ Item } & \multicolumn{3}{|c|}{ Treatment $^{1}$} & \multicolumn{3}{|c|}{$P$-value ${ }^{2}$} \\
\hline & 0 & 0.5 & 1 & TRT & Linear & Quadratic \\
\hline \multicolumn{7}{|c|}{ Respiration rate, ${ }^{3}$ breaths $/ \mathrm{min}$} \\
\hline Morning & $44.8 \pm 1.2$ & $53.9 \pm 1.3$ & $49.3 \pm 1.3$ & 0.001 & 0.02 & 0.001 \\
\hline Afternoon & $55.2 \pm 1.2$ & $60.8 \pm 1.3$ & $58.4 \pm 1.3$ & 0.008 & 0.07 & 0.01 \\
\hline \multicolumn{7}{|c|}{ Rectal temperature, ${ }^{4}{ }^{\circ} \mathrm{C}$} \\
\hline Morning & $38.62 \pm 0.05$ & $38.65 \pm 0.05$ & $38.62 \pm 0.05$ & 0.82 & 0.99 & 0.53 \\
\hline
\end{tabular}

${ }^{1}$ Amount (grams per day) of live yeast (Saccharomyces cerevisiae strain CNCM I-1077, Levucell SC20, Lallemand Animal Nutrition, Milwaukee, WI) containing a minimum of 20 billion cells/g.

${ }^{2} \mathrm{TRT}=$ effect of treatment; linear $=$ linear effect of amount of live yeast fed; quadratic $=$ quadratic effect of amount of live yeast fed.

${ }^{3}$ For respiration rate, the effects of period of the day (morning vs. afternoon; $\left.P<0.0001\right)$ and the interaction between treatment and period $(P$ $=0.01$ ) were significant.

${ }^{4}$ For rectal temperature, the effect of period of the day (morning vs. afternoon; $P<0.0001$ ) was significant, but no interaction between treatment and period $(P=0.67)$ was observed.

ment effect was observed for vaginal temperature of cows, which averaged $38.89 \pm 0.24^{\circ} \mathrm{C}$. In all treatments, rectal temperature increased $(P<0.01)$ by approximately $0.5^{\circ} \mathrm{C}$ in the afternoon compared with that in the morning (Table 3). No treatment or treatment-byparity interactions were observed for rectal temperature of dairy cows. In all treatments, respiration rate increased $(P<0.01)$ in the afternoon compared with the morning (Table 3$)$. For both periods, a quadratic $(P$ $<0.01)$ response to feeding LY was observed, and cows fed $0.5 \mathrm{~g} / \mathrm{d}$ had the highest respiratory frequency; those fed $1 \mathrm{~g} / \mathrm{d}$ were intermediate; and control cows had the lowest values.

\section{Lactation Performance}

The DMI of cows was not affected by the inclusion of LY in the diet, and it averaged $20.6 \pm 0.4 \mathrm{~kg} / \mathrm{d}$ (Table $4)$, with no interaction between treatment and parity. Milk yield tended $(P=0.10)$ to increase linearly, a 1.4 $\mathrm{kg} / \mathrm{d}$ difference between 0 and $1 \mathrm{~g} / \mathrm{d}$ treatments, with incremental feeding of LY. Similarly, feeding LY tended to increase $(P=0.07)$ and increased $(P=0.04)$ yields of $3.5 \% \mathrm{FCM}$ and ECM, respectively. The increment in ECM yield with increasing dose of LY resulted in a linear increase $(P=0.02)$ in feed efficiency, evaluated as $\mathrm{kg}$ of FCM or ECM per $\mathrm{kg}$ of DMI (Table 4). Cows fed $1 \mathrm{~g} / \mathrm{d}$ of LY produced an extra $0.13 \mathrm{~kg}$ of ECM per each $\mathrm{kg}$ of DMI. Concentration of milk fat did not differ among treatments, but true protein tended $(P=0.08)$ to increase with increasing dose of LY. Fat yield tended $(P=0.09)$ to increase and true protein yield increased $(P<0.01)$ linearly with increasing dose of LY. Milk lactose concentration did not differ among treatments, but lactose yield tended $(P=0.08)$ to increase linearly with increasing dose of LY. The NE content of milk did not differ among treatments and had a mean value of $0.66 \mathrm{Mcal} / \mathrm{kg}$. No interactions were observed between treatment and parity for yields of milk, 3.5\% FCM, ECM, milk components, or feed efficiency. The milk SCS did not differ among treatments and resulted in a mean of $2.96 \pm 0.34$.

\section{Measures of Energy Status and Plasma Metabolites}

The BCS and BW of cows did not differ with addition of LY to the diet (Table 5). Cows gained BW (0.34 $\mathrm{kg} / \mathrm{d}$ ) and BCS (0.33 units) during the 77-d experiment, but treatment did not affect those responses. The calculated $\mathrm{NE}$ balance based on the $\mathrm{NE}_{\mathrm{L}}$ content of the diet from NRC (2001) decreased $(P=0.02)$ linearly with added LY, and cows fed $0 \mathrm{~g} / \mathrm{d}$ had a slight positive NE balance, whereas those fed $1.0 \mathrm{~g} / \mathrm{d}$ had a slight negative NE balance during the experiment. No interactions between treatment and parity were observed for $\mathrm{BW}, \mathrm{BCS}$, or NE balance.

The $\mathrm{NE}_{\mathrm{L}}$ content of diets was estimated based on daily needs for maintenance, $\mathrm{NE}_{\mathrm{L}}$ secreted in milk, daily BW change, and DMI of cows. Supplementing LY resulted in a linear increased $(P=0.04)$ of estimated energy content of the diet by $2.3 \%$ and $5.2 \%$ in cows fed 0.5 and $1 \mathrm{~g} / \mathrm{d}$ compared with cows not supplemented with LY (Table 5).

Feeding LY resulted in a linear increase $(P=0.04)$ in plasma concentrations of fatty acids. Treatment did not affect concentrations of urea $\mathrm{N}$ in plasma. A treatment-by-parity interaction $(P<0.01)$ was observed for plasma glucose concentrations: for multiparous cows, plasma glucose was highest with feeding $1 \mathrm{~g} / \mathrm{d}$ of LY $(0 \mathrm{~g} / \mathrm{d}=3.34 \pm 0.06,0.5 \mathrm{~g} / \mathrm{d}=3.33 \pm 0.06$, and 1 $\mathrm{g} / \mathrm{d}=3.51 \pm 0.06 \mathrm{~m} M$ ), whereas for primiparous cows, plasma glucose was lowest among those fed $1 \mathrm{~g} / \mathrm{d}$ of LY 
Table 4. Effects on lactation performance of feeding increasing amounts of live yeast to cows exposed to heat stress (LSM \pm SEM)

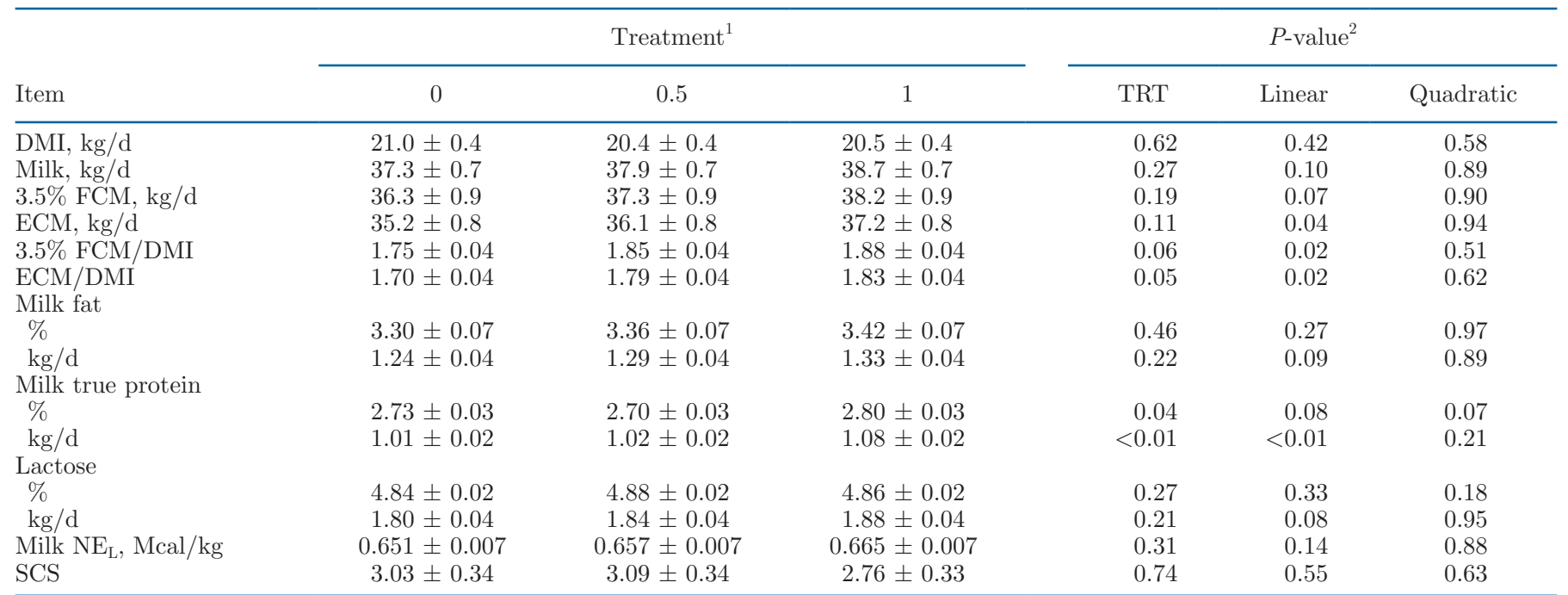

${ }^{1}$ Amount (grams per day) of live yeast (Saccharomyces cerevisiae strain CNCM I-1077, Levucell SC20, Lallemand Animal Nutrition, Milwaukee, WI) containing a minimum of 20 billion cells/g.

${ }^{2} \mathrm{TRT}=$ effect of treatment; linear $=$ linear effect of amount of live yeast fed; quadratic $=$ quadratic effect of amount of live yeast fed.

$(0 \mathrm{~g} / \mathrm{d}=3.50 \pm 0.05,0.5 \mathrm{~g} / \mathrm{d}=3.34 \pm 0.05$, and $1 \mathrm{~g} / \mathrm{d}$ $=3.28 \pm 0.05 \mathrm{mM})$.

\section{Digestibility, Ruminal Parameters, and Acute-Phase Proteins}

Apparent digestibility in the total digestive tract was affected by LY. The intake of DM during digestibility measurements did not differ among treatments (Table 6). Feeding LY resulted in a linear increase $(P$ $<0.05)$ in digestibility of DM, OM, CP, and NDF. No treatment-by-parity interaction was observed for any of the digestibility measures.

Ruminal fluid $\mathrm{pH}$ tended to increase $(P=0.07)$ linearly with increasing amount of LY fed to dairy cows
(Table 7). A smaller $(P=0.03)$ proportion of cows fed $1 \mathrm{~g} / \mathrm{d}$ had ruminal $\mathrm{pH}$ below 5.80, compared with those fed $0 \mathrm{~g} / \mathrm{d}$. A small concentration of lactate was detected in ruminal fluid in most samples, but the proportion of cows with detectable lactate in ruminal fluid tended $(P$ $=0.08)$ to be lower with increasing amount of LY fed. In fact, the concentration of lactate in ruminal fluid was less $(P=0.02)$ with increasing LY (Table 7$)$. The concentration of total SCFA in ruminal fluid increased $(P=0.02)$ linearly with increasing amount of LY fed, because of an increase $(P<0.01)$ in concentration of acetate. Concentrations of propionate, butyrate, isobutyrate, and valerate did not differ with treatment, but those of isovalreate increased $(P=0.01)$ with feeding LY. Despite changes in acetate concentrations, the ra-

Table 5. Effects on measures of energy status and plasma concentrations of metabolites of feeding increasing amounts of live yeast to cows exposed to heat stress $(\mathrm{LSM} \pm \mathrm{SEM})$

\begin{tabular}{|c|c|c|c|c|c|c|}
\hline \multirow[b]{2}{*}{ Item } & \multicolumn{3}{|c|}{ Treatment $^{1}$} & \multicolumn{3}{|c|}{$P$-value ${ }^{2}$} \\
\hline & 0 & 0.5 & 1 & TRT & Linear & Quadratic \\
\hline BCS change, wk 1 to 11 & $0.35 \pm 0.04$ & $0.34 \pm 0.04$ & $0.29 \pm 0.04$ & 0.42 & 0.24 & 0.55 \\
\hline $\mathrm{BW}, \mathrm{kg}$ & $613.4 \pm 5.0$ & $609.1 \pm 5.1$ & $614.3 \pm 5.0$ & 0.71 & 0.89 & 0.42 \\
\hline BW change, $\mathrm{kg} / \mathrm{d}$ & $0.39 \pm 0.13$ & $0.32 \pm 0.13$ & $0.31 \pm 0.13$ & 0.89 & 0.66 & 0.86 \\
\hline Energy balance, Mcal/d & $0.90 \pm 0.64$ & $-0.61 \pm 0.64$ & $-1.34 \pm 0.64$ & 0.05 & 0.02 & 0.63 \\
\hline Glucose, $\mathrm{m} M$ & $3.42 \pm 0.04$ & $3.33 \pm 0.04$ & $3.39 \pm 0.04$ & 0.22 & 0.62 & 0.10 \\
\hline Urea $\mathrm{N}, \mathrm{m} M$ & $4.04 \pm 0.09$ & $4.03 \pm 0.09$ & $3.98 \pm 0.09$ & 0.91 & 0.68 & 0.88 \\
\hline
\end{tabular}

${ }^{1}$ Amount (grams per day) of live yeast (Saccharomyces cerevisiae strain CNCM I-1077, Levucell SC20, Lallemand Animal Nutrition, Milwaukee, WI) containing a minimum of 20 billion cells/g.

${ }^{2} \mathrm{TRT}=$ effect of treatment; linear = linear effect of amount of live yeast fed; quadratic = quadratic effect of amount of live yeast fed. 
Table 6. Effects on total-tract apparent digestibility of feeding increasing amounts of live yeast to cows exposed to heat stress (LSM \pm SEM)

\begin{tabular}{|c|c|c|c|c|c|c|}
\hline \multirow[b]{2}{*}{ Item } & \multicolumn{3}{|c|}{ Treatment $^{1}$} & \multicolumn{3}{|c|}{$P$-value ${ }^{2}$} \\
\hline & 0 & 0.5 & 1 & TRT & Linear & Quadratic \\
\hline $\mathrm{DM}$ & $68.3 \pm 0.9$ & $70.9 \pm 1.0$ & $71.8 \pm 1.0$ & 0.03 & 0.01 & 0.46 \\
\hline $\mathrm{OM}$ & $69.6 \pm 0.9$ & $71.9 \pm 0.9$ & $72.9 \pm 0.9$ & 0.02 & $<0.01$ & 0.49 \\
\hline $\mathrm{CP}$ & $65.1 \pm 1.3$ & $68.8 \pm 1.3$ & $70.4 \pm 1.3$ & $<0.01$ & $<0.01$ & 0.47 \\
\hline
\end{tabular}

${ }^{1}$ Amount (grams per day) of live yeast (Saccharomyces cerevisiae strain CNCM I-1077, Levucell SC20, Lallemand Animal Nutrition, Milwaukee, WI) containing a minimum of 20 billion cells/g.

${ }^{2} \mathrm{TRT}=$ effect of treatment; linear = linear effect of amount of live yeast fed; quadratic = quadratic effect of amount of live yeast fed.

tio of acetate to propionate and the molar proportions of individual SCFA, relative to the total SCFA, did not differ among treatments. The concentration of $\mathrm{NH}_{3}-\mathrm{N}$ in ruminal fluid tended $(P=0.07)$ to increase quadratically with dose of LY. Increasing the dose of LY up to 1 $\mathrm{g} / \mathrm{d}$ tended $(P<0.10)$ to reduce the concentrations of haptoglobin and acid-soluble protein and reduced $(P=$ 0.04) the concentrations of serum amyloid A in plasma of dairy cows. No interactions were observed between treatment and parity for total-tract apparent digestibility of nutrients and concentrations of SCFA, lactate, or $\mathrm{NH}_{3}-\mathrm{N}$ in ruminal fluid and those of acute-phase proteins in blood plasma.

\section{Feeding Behavior}

Cows in all 3 treatments had consistent patterns of eating and ruminating (Supplemental Figure S2A; https://doi.org/10.3168/jds.2019-17303). They had 2 important bouts of intake, immediately after each milking, in which approximately $90 \%$ of the cows spent time consuming feed, and a less-pronounced period of intake immediately before the morning milking. A larger proportion of cows spent time eating in the first $10 \mathrm{~h}$ after the morning milking than after the evening milking. On the other hand, the diurnal pattern of cows ruminating only was more pronounced at late night and

Table 7. Effects on ruminal fluid composition and plasma acute-phase proteins of feeding increasing amounts of live yeast to cows exposed to heat stress $(\mathrm{LSM} \pm \mathrm{SEM})$

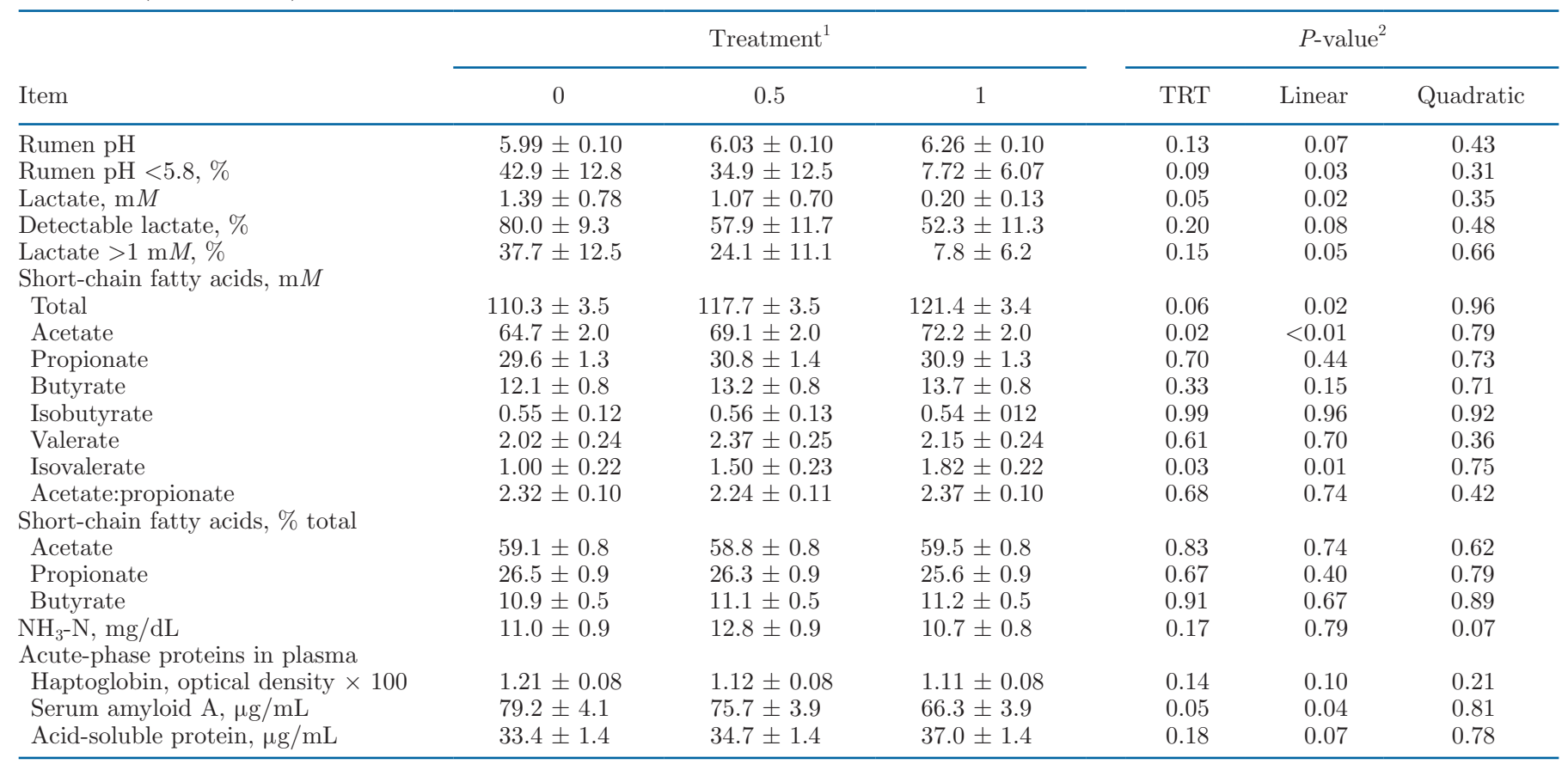

${ }^{1}$ Amount (grams per day) of live yeast (Saccharomyces cerevisiae strain CNCM I-1077, Levucell SC20, Lallemand Animal Nutrition, Milwaukee, WI) containing a minimum of 20 billion cells/g.

${ }^{2} \mathrm{TRT}=$ effect of treatment; linear = linear effect of amount of live yeast fed; quadratic = quadratic effect of amount of live yeast fed. 
Table 8. Effects on feeding behavior of feeding increasing amounts of live yeast to cows exposed to heat stress (LSM \pm SEM)

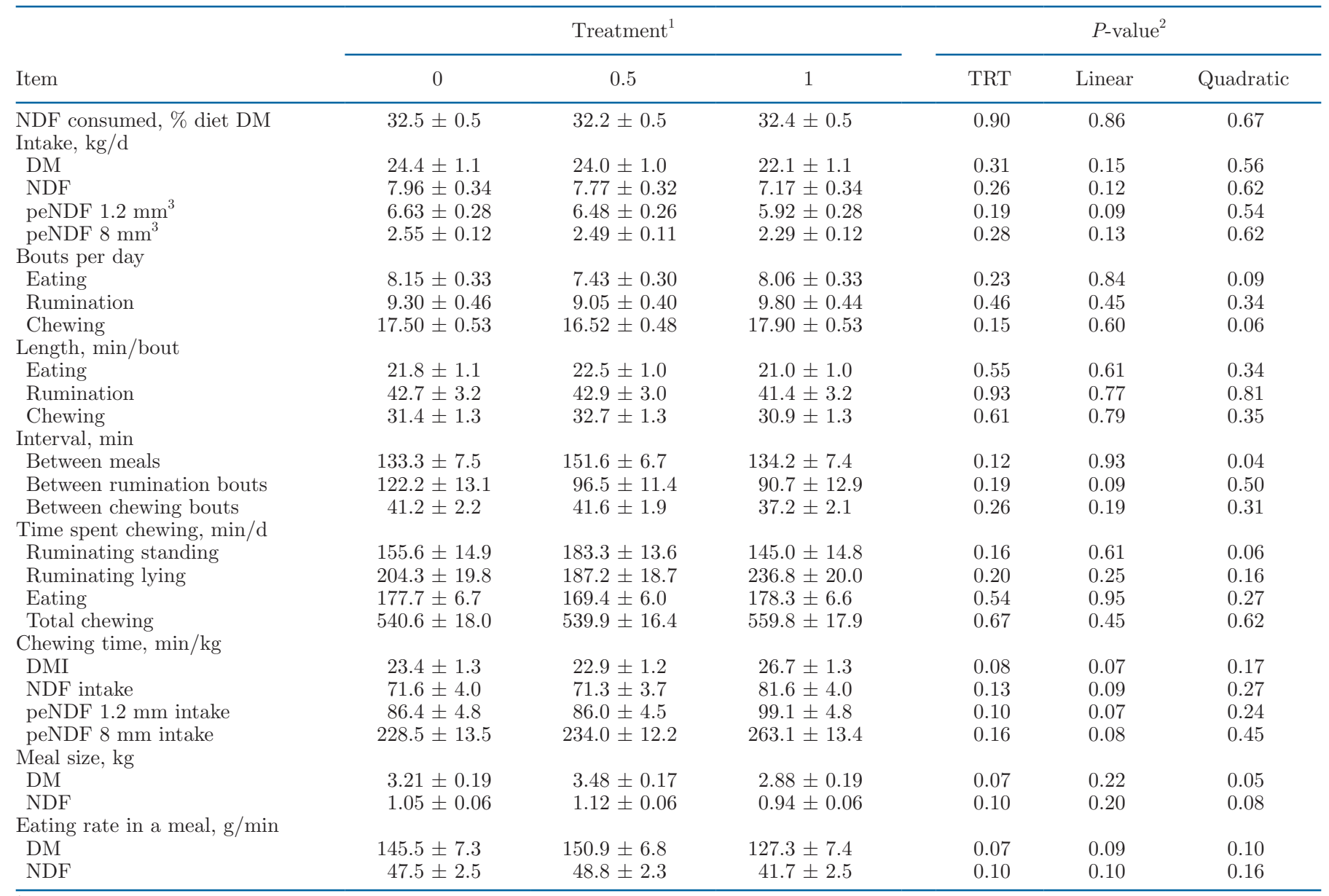

${ }^{1}$ Amount (grams per day) of live yeast (Saccharomyces cerevisiae strain CNCM I-1077, Levucell SC20, Lallemand Animal Nutrition, Milwaukee, WI) containing a minimum of 20 billion cells/g.

${ }^{2} \mathrm{TRT}=$ effect of treatment; linear = linear effect of amount of live yeast fed; quadratic = quadratic effect of amount of live yeast fed.

${ }^{3}$ peNDF $=$ physically effective NDF, based on the amount of NDF retained in the sieves with diameter greater than 1.2 or 8 mm.

early morning, after the evening milking (Supplemental Figure S2B; https://doi.org/10.3168/jds.2019-17303).

The percentage of NDF in the diet consumed by cows during the feeding behavior periods did not differ among treatments and resulted in a mean of $32.4 \%$ (Table 8). Similar to the entire experimental period, intake of DM during the $4 \mathrm{~d}$ of feeding behavior evaluation did not differ among treatments and resulted in a mean of 23.5 $\mathrm{kg}$ of DM and $7.6 \mathrm{~kg}$ of NDF. Because of minor changes in particle size distribution (Supplemental Figure S3; https://doi.org/10.3168/jds.2019-17303) and the numerical difference in NDF intake, the consumption of peNDF $1.2 \mathrm{~mm}$ tended $(P=0.09)$ to decrease linearly with addition of LY. Nevertheless, the intake of peNDF $8 \mathrm{~mm}$ did not differ with treatment. Cows fed 0 and 1 $\mathrm{g} / \mathrm{d}$ of LY tended $(P=0.09)$ to have more daily meals than those fed $0.5 \mathrm{~g} / \mathrm{d}$ of LY, but bouts of rumination only did not differ among treatments and had a mean of $9.4 /$ d. Total chewing bouts tended $(P=0.06)$ to change quadratically with level of LY fed. The length of each bout of intake (21.8 min), rumination only (42.3 $\mathrm{min})$, and chewing $(31.7 \mathrm{~min})$ did not differ with treatment.

Intervals between meals responded quadratically $(P$ $=0.04)$ to the amount of LY fed: cows fed $0.5 \mathrm{~g} / \mathrm{d}$ had a longer interval between meals than those fed either 0 or $1 \mathrm{~g} / \mathrm{d}$. The interval between bouts of rumination tended $(P=0.09)$ to decrease linearly with increasing dietary LY. A tendency $(P=0.06)$ for interaction between treatment and parity was observed for interval between chewing bouts. For primiparous cows, treatment had no effect $(P>0.45)$ on interval between chewing bouts $(34.1 \pm 3.3$, vs. $37.1 \pm 2.8$, vs. $37.4 \pm 2.8 \mathrm{~min}$ for cows fed $0,0.5$, and $1 \mathrm{~g} / \mathrm{d}$, respectively), whereas for multiparous cows a linear $(P=0.01)$ decline in the interval was observed with increasing amounts of LY (48.2 \pm 
2.9, vs. $46.2 \pm 2.6$, vs. $36.9 \pm 3.2 \mathrm{~min}$ for cows fed 0 , 0.5 , and $1 \mathrm{~g} / \mathrm{d}$, respectively).

Time spent chewing did not differ among treatments (Table 8). Cows spent a mean of 546.8 min a day chewing. Nevertheless, the time spent chewing per $\mathrm{kg}$ of DM, NDF, and peNDF tended $(P<0.10)$ to increase linearly with increasing amounts of LY fed. The meal size was smaller $(P=0.05)$ for cows fed $1 \mathrm{~g} / \mathrm{d}$ of $\mathrm{LY}$, which resulted in a tendency $(P=0.08)$ for a smaller intake of NDF per meal. Increasing the amount of LY tended $(P<0.10)$ to linearly decrease the rate of DM and NDF consumption per eating bout. Because of eating pattern and time of feeding (Supplemental Figure S2; https://doi.org/10.3168/jds.2019-17303), the largest proportion of DM consumed occurred in the first $2 \mathrm{~h}$ after feeding (Supplemental Figure S4; https:// doi.org/10.3168/jds.2019-17303). An interaction $(P<$ 0.01 ) between treatment and hour relative to feeding was observed for the pattern of DMI. In the first $2 \mathrm{~h}$ after feeding, cows fed $1 \mathrm{~g} / \mathrm{d}$ of LY consumed less $(P<$ $0.01)$ DM than did those fed 0 or $0.5 \mathrm{~g} / \mathrm{d}$ of LY $(28.2 \pm$ 0.95 , vs. $29.6 \pm 0.84$, vs. $24.7 \pm 0.93 \%$ for $0,0.5$, and $1 \mathrm{~g} / \mathrm{d}$, respectively). On the other hand, at $10 \mathrm{~h}$ after feeding, cows fed $0 \mathrm{~g} / \mathrm{d}$ consumed a smaller $(P<0.02)$ percentage of the daily DM than did those fed 0.5 or 1 g/d (10.5 \pm 0.95 , vs. $13.2 \pm 0.84$, vs. $13.9 \pm 0.94 \%$ for $0,0.5$, and $1 \mathrm{~g} / \mathrm{d}$, respectively).

\section{DISCUSSION}

Heat stress results in major detrimental effects on dairy cows, and strategies such as dietary manipulations that complement environmental modifications to improve intake and digestion are continually sought under periods of heat stress. Microbial additives have been supplemented to lactating dairy cows exposed to high ambient temperatures, and some seem either to alleviate signs of heat stress by reducing rectal temperature and respiration rate (Huber et al., 1994), or to improve lactation performance by mechanisms related to diet digestion (Dias et al., 2018a,b) or by changes in feeding behavior (Bach et al., 2007). In fact, supplementing LY to dairy cows in the present experiment improved digestion of fiber and $\mathrm{CP}$, which resulted in increased OM digestion and improved yield of ECM and efficiency of feed conversion into ECM and FCM in heat-stressed dairy cows. These results corroborate those of past studies, in which cows under heat stress fed diets supplemented with LY showed increased yields of milk, FCM, or feed efficiency (Moallem et al., 2009; Dias et al., 2018c), or in which cows fed YC showed improved yield of milk or feed efficiency (Schingoethe et al., 2004; Bruno et al., 2009).
During the present experiment, cows were exposed constantly to heat stress, based on the mean daily THI consistently greater than 75 and vaginal temperatures greater than $39.0^{\circ} \mathrm{C}$ in most of the afternoon and early evening. It has been suggested that dairy cows display signs of heat stress when THI is greater than 72 (Armstrong, 1994), although more recent evaluations, with cows producing 35 to $40 \mathrm{~kg}$ of milk/d, showed that losses in production seem to start when the minimum daily THI is at least 65 or when the daily mean THI is 68 (Collier et al., 2012). Treatment with LY did not affect vaginal or rectal temperatures, and it increased respiratory frequency. A few experiments have suggested that microbial additives have the potential to alleviate signs of heat stress (Huber et al., 1994; Salvati et al., 2015; Dias et al., 2018c). In particular, LY or a mixture of LY with YC reduced respiration rate and rectal and skin temperatures (Salvati et al., 2015; Dias et al., 2018c), benefits partially attributable to changes in plasma concentrations of niacin and improved evaporative heat loss (Dias et al., 2018c). It is possible that the effects of LY on regulation of body temperature and responses to heat stress are influenced by the strain and amount of $S$. cerevisiae supplemented. Dias et al. (2018c) supplemented dairy cows with a YC containing only dead S. cerevisiae cells (total of $2.85 \times 10^{10} \mathrm{cfu}$ of dead cells/cow per day), and Salvati et al. (2015) supplemented cows with a mixture of $25 \times 10^{10} \mathrm{cfu}$ of live cells and $5 \times 10^{10} \mathrm{cfu}$ of dead cells/cow per day. These amounts are 2 to 17 times greater than those fed in treatment $0.5 \mathrm{~g} / \mathrm{d}$ and almost 7 times more than the dose of $S$. cerevisiae fed in treatment $1 \mathrm{~g} / \mathrm{d}$.

Supplementing LY tended to improve yields of milk and $3.5 \%$ FCM, and improved yield of ECM. The benefits of LY on yields of ECM were dose dependent, and the increment was linear within the doses used. Others have shown benefits of supplementing LY (Moallem et al., 2009; Salvati et al., 2015) or YC (Bruno et al., 2009) on lactation performance in dairy cows under heat stress. In some experiments under heat stress, supplementing diets with LY also improved efficiency of conversion of DMI into FCM (Moallem et al., 2009), which has also been observed with YC (Schingoethe et al., 2004). Supplementing LY did not affect DMI of cows, so the increments in yields of FCM and ECM cannot be attributed to increased intake of nutrients. On the other hand, feeding LY improved total-tract digestibility of $\mathrm{OM}, \mathrm{CP}$, and $\mathrm{NDF}$, which would result in increased content of digestible energy of diets to support additional milk yield. Desnoyers et al. (2009) reviewed the literature on feeding LY and YC to ruminants and found that supplementation with LY increased DMI and total-tract OM digestibility. During measurements 
of digestibility at the end of the experiment, treatments did not affect DMI and, therefore, changes in digestibility are unlikely to be related to changes in intake and retention of dietary particles in the rumen. On the other hand, total-tract digestibility of $\mathrm{OM}$ increased in part because of improved CP and NDF digestion, likely because of increased ruminal digestion. Feeding LY resulted in a linear increase in the concentration of total SCFA in ruminal fluid, mostly because of an increase in acetate, which suggests improved NDF digestion in the rumen.

One of the proposed mechanisms of action of LY is the increased activity of microbial fibrolytic enzymes, which results in enhanced ruminal fermentation with less $\mathrm{NH}_{3}-\mathrm{N}$ and more SCFA in the ruminal fluid (Chaucheyras-Durand and Fonty, 2001). Live yeast has been shown to scavenge oxygen in the rumen (Newbold et al., 1996), which reduces the rumen redox and is thought to be part of its mechanism of action to help stimulate growth of certain microorganisms that help stabilize ruminal pH (Marden et al., 2008). Live yeast has been shown to prevent accumulation of lactate in ruminal fluid and increase NDF digestion (Marden et al., 2008). In fact, using $16 \mathrm{~S}$ rRNA gene sequencing methods, Pinloche et al. (2013) reported a relationship between ruminal redox potential and the activity of cellulolytic and lactate-utilizing bacteria. Feeding S. cerevisiae to gnotobiotic lambs enhanced the establishment of ciliate protozoa in the rumen (Chaucheyras-Durand and Fonty, 2002), and addition of S. cerevisiae to an in vitro culture of Streptococcus bovis and Megasphaera elsdenii reduced the availability of glucose for lactate synthesis and increased utilization of L-lactate by $M$. elsdenii (Chaucheyras et al., 1996). Diets containing high concentrations of starch usually favor a reduced ruminal $\mathrm{pH}$, and heat stress may further decrease ruminal $\mathrm{pH}$ and disturb ruminal function (Mishra et al., 1970). Supplementing S. cerevisiae stimulates microorganisms that use lactic acid as substrate, which might result a more stable rumen environment (Chaucheyras et al., 1996; Jiang et al., 2017). Several experiments have shown that $S$. cerevisiae increased the populations of total and cellulolytic bacteria in ruminal fluid of dairy cows (Wiedmeier et al., 1987; Harrison et al., 1988). Based on sequencing of rumen microbial DNA, Jiang et al. (2017) showed that LY increased the relative abundance of cellulolytic and lactate-utilizing microorganisms. In the present experiment, LY increased ruminal $\mathrm{pH}$ and reduced the proportion of cows with ruminal $\mathrm{pH}$ below 5.80, as well as the proportion of cows with detectable lactate and cows with lactate $>1$ $\mathrm{m} M$ in ruminal fluid, all of which are expected to improve survival and activity of fiber-digesting bacteria. Collectively, these data suggest that supplementing LY to cows resulted in a more stable ruminal $\mathrm{pH}$, which would benefit NDF digestion in the rumen, particularly in diets that favor acidic conditions in the rumen (Dias et al., 2018b). Even though only a few experiments have evaluated the effects of yeast products on ruminal $\mathrm{pH}$ in cows under heat stress, the results demonstrated either a numerical increase or a tendency for increase in pH (Moallem et al., 2009; Salvati et al., 2015).

In some experiments in which cows were fed diets supplemented with YC, it was suggested that an alternative explanation for the increased ruminal $\mathrm{pH}$ or improved ruminal function might be a change in the site of starch digestion. Allen and Ying (2012) showed that $\mathrm{YC}$ reduced the rate of starch digestion in the rumen in cows with increased DMI, benefiting highproducing cows. Dias et al. (2018b) showed that feeding $\mathrm{YC}$ reduced ruminal starch digestion in cows fed a high-starch diet. It is unknown whether LY would have a similar effect to that of YC; however, several of the proposed mechanisms by which $S$. cerevisiae affects ruminal fermentation are shared between LY and YC; therefore, it is possible that a similar effect might have been observed, although we can only speculate, as ruminal digestion could not be evaluated in the present experiment.

An increase in fiber and OM digestion in the rumen could favor $\mathrm{N}$ recycling and increase microbial protein yield, which might explain the increased CP digestion. Also, an increase in ruminal digestion of fiber and $\mathrm{OM}$ would reduce the amount of $\mathrm{OM}$ reaching the large intestine and therefore reduce the amount of $\mathrm{N}$ recycled to the cecum and colon, which would be expected to reduce fecal $\mathrm{N}$ and improve $\mathrm{CP}$ digestion. Others have shown an increase in ruminal digestion of NDF and total-tract digestibility of CP when cows were supplemented with S. cerevisiae (Dias et al., 2018b). In vitro work has shown that incorporation of a culture of $S$. cerevisiae altered microbial fermentation and increased digestibility of DM and CP (Miller-Webster et al., 2002), which is expected to enhance microbial growth (Erasmus et al., 1992). Although ruminal digestion was not evaluated in the present experiment, the increment in NDF digestion, combined with the increase in ruminal fluid acetate content with supplementing 1 $\mathrm{g} / \mathrm{d}$ of LY suggests improved ruminal digestion of fiber, perhaps the result of the more stable $\mathrm{pH}$ or increased rumen fibrolytic bacteria.

Concentrations of haptoglobin and acid-soluble protein tended to decrease and that of serum amyloid A decreased linearly with level of LY fed. These are considered positive acute-phase proteins that increase in plasma, as part of the innate immune system, in response to an inflammatory insult (Cray et al., 2009). These proteins are synthesized by hepatocytes after 
release of cytokines from immune cells at the site of insult (Murata et al., 2004). It is well established that gastrointestinal insults and subacute ruminal acidosis can induce an acute-phase response in cattle, in part because of changes in ruminal fermentation that cause low ruminal $\mathrm{pH}$ and bacterial death with increased release of microbial-associated molecular patterns such as LPS. An increase in ruminal LPS content is able to induce an acute-phase response in cattle (Plaizier et al., 2008). Supplementing YC improved ruminal $\mathrm{pH}$ in cows fed a high-starch diet, in part because of less lactate, and tended to reduce the concentration of haptoglobin (Dias et al., 2018a). The same authors showed that rumen papillae of cows supplemented with YC had reduced expression of toll-like receptor 4, perhaps suggesting a reduced effect of LPS-induced inflammation in the rumen epithelium (Dias et al., 2018b). Altogether, supplementing $S$. cerevisiae affects ruminal fermentation with reduced lactate concentration and increased $\mathrm{pH}$, which might attenuate the risk of inflammatory insults and the subsequent acute-phase response. A reduction in acute-phase proteins might preserve nutrients otherwise used to resolve inflammation, to support productive functions such as milk synthesis.

Few experiments have evaluated the effect of supplementing diets of dairy cows with $\mathrm{LY}$ or $\mathrm{YC}$ on eating patterns and feeding behavior of dairy cows. Bach et al. (2007) fed 10 billion cfu of LY to cows receiving a partial mixed diet with extra concentrates during milking. Supplementing LY increased meal frequency, which was suggested to partially explain the more stable diurnal $\mathrm{pH}$ of the ruminal fluid (Bach et al., 2007). Indeed, both LY (Bach et al., 2007; DeVries and Chevaux, 2014) and YC (Dias et al., 2018a) supplementation to diets of dairy cows resulted in reduced intermeal intervals, smaller meal sizes, longer periods of rumination, and increased eating and chewing bouts compared with cows fed diets without supplemental S. cerevisiae. Chewing time per kilogram of DM or NDF consumed tended to increase linearly with feeding LY, to a large extent because of the shorter interval between rumination bouts in cows fed the treatment with $1 \mathrm{~g} / \mathrm{d}$. These changes in feeding behavior resulted in a tendency to reduce eating rate, which might have favored NDF and OM digestion in the rumen. The alterations in eating rate might have slowed the release of organic acids from $\mathrm{OM}$ digestion that help explain the reduced concentration of lactate hours after a meal. We speculate that the extra time spent chewing per unit of feed consumed may deliver more saliva to the rumen, which should increase the buffering capacity, favoring an increased ruminal $\mathrm{pH}$. It is important to note that the effects of LY or YC on feeding behavior in dairy cows are not always observed. Ferraretto et al. (2012) fed lactating dairy cows a high-starch diet supplemented with 0,2 , or $4 \mathrm{~g} / \mathrm{d}$ of an LY product and observed no differences in feeding behavior, which was similar to the findings of Salvati et al. (2015) and Dias et al. (2018c), the latter 2 experiments with cows under heat stress. The reason for heterogeneity in responses to LY on feeding behavior are unknown. Perhaps changes in meal patterns and time spent ruminating might be related to rate and site of digestion, in particular of starch. If $S$. cerevisiae influences the site of starch digestion (Allen and Ying, 2012; Dias et al., 2018b), such changes would result in less release of propionate, a powerful hypophagic compound in ruminants that alters feeding behavior (Allen et al., 2009), which could affect how dairy cows respond to diets supplemented with yeast products.

The improvements in yield of ECM in the absence of changes in DMI did not result in smaller BCS, lighter $\mathrm{BW}$, or less gain of BCS or BW. An increase in plasma fatty acids was observed with LY, but the values were low, comparable with those of cows maintaining or gaining body tissue. The $\mathrm{NE}_{\mathrm{L}}$ content of the diet estimated using the observed responses to treatments and DMI showed that supplementing LY increased dietary energy in a dose-dependent manner, respectively 2.3 and $5.2 \%$ in cows fed 0.5 or $1 \mathrm{~g}$ of LY daily. The calculated $\mathrm{NE}_{\mathrm{L}}$ content of the diet based on the NRC (2001) and adjusted for lactation, BW, and DMI was $1.68 \mathrm{Mcal} /$ $\mathrm{kg}$, a value $2.3 \%$ smaller than that estimated using the observed milk energy yield, BW, daily change in BW, and DMI in cows fed $0 \mathrm{~g}$ of LY. On the other hand, the estimated $\mathrm{NE}_{\mathrm{L}}$ contents of the diet fed to cows receiving 0 or $1 \mathrm{~g}$ of LY changed $5.2 \%$, an amount sufficient to justify the $2.0 \mathrm{~kg}$ additional ECM observed in the experiment.

\section{CONCLUSIONS}

Feeding live yeast to early-lactation dairy cows under heat stress improved yield of energy-corrected milk without affecting DMI and, therefore, increased efficiency of conversion of DM consumed into ECM by $7.4 \%$. The improvement in feed efficiency is likely related to improved digestion of fiber, protein, and OM, perhaps because of direct effects of $S$. cerevisiae on rumen microbial metabolism that favored a more stable ruminal environment for fiber digestion, or because of changes in feeding behavior with reduced eating rate and increased chewing time per unit of DM and NDF consumed, which should favor digestion. The differences in production resulted in an increase in estimated $\mathrm{NE}_{\mathrm{L}}$ content of the diet of $5.2 \%$ when $1 \mathrm{~g} / \mathrm{d}$ was fed. Collectively, these results support the inclusion of at least $3.76 \times 10^{10}$ billion cells of $S$. cerevisiae of the strain studied in diets of dairy cows under heat stress, 
to maintain a more stable ruminal environment, improve digestion, and increase productive performance and feed efficiency.

\section{ACKNOWLEDGMENTS}

The authors thank the staff of the University of Florida (Gainesville) Dairy Unit and help from Davi B. Araújo, Rafael Bisinotto, Leandro F. Greco, Leonardo T. Martins, Carla Foditsch, Miriam Garcia, Eduardo S. Ribeiro, J. H. Shin, Flávio T. Silvestre, and Daniella Wang from the University of Florida. We thank James Sullivan and Laurent Dussert from Lallemand Animal Nutrition (Milwaukee, WI) for assistance with the experiment. Partial financial support for this project was provided by Lallemand Animal Nutrition.

\section{REFERENCES}

Allen, M. S., B. J. Bradford, and M. Oba. 2009. Board invited review: The hepatic oxidation theory of the control of feed intake and its application to ruminants. J. Anim. Sci. 87:3317-3334.

Allen, M. S., and Y. Ying. 2012. Effects of Saccharomyces cerevisiae fermentation product on ruminal starch digestion are dependent upon dry matter intake for lactating cows. J. Dairy Sci. 95:65916605 .

Armstrong, D. V. 1994. Heat stress interaction with shade and cooling. J. Dairy Sci. 77:2044-2050.

Bach, A., C. Iglesias, and M. Devant. 2007. Daily rumen pH pattern of loose-housed dairy cattle as affected by feeding pattern and live yeast supplementation. Anim. Feed Sci. Technol. 136:146-153.

Bruno, R. G., H. M. Rutigliano, R. L. Cerri, P. H. Robinson, and J. E. P. Santos. 2009. Effect of feeding Saccharomyces cerevisiae on performance of dairy cows during summer heat stress. Anim. Feed Sci. Technol. 150:175-186.

Canale, A., M. E. Valente, and A. Ciotti. 1984. Determination of volatile carboxylic acids (C1-C5) and lactic acid in aqueous acid extracts of silage by high-performance liquid chromatography. J. Sci. Food Agric. 35:1178-1182.

Chaucheyras, F., G. Fonty, G. Bertin, J. M. Salmon, and P. Gouet. 1996. Effects of a strain of Saccharomyces cerevisiae (Levucell $\mathrm{SC} 1$ ), a microbial additive for ruminants, on lactate metabolism in vitro. Can. J. Microbiol. 42:927-933.

Chaucheyras-Durand, F., and G. Fonty. 2001. Establishment of cellulolytic bacteria and development of fermentative activities in the rumen of gnotobiotically-reared lambs receiving the microbial additive Saccharomyces cerevisiae CNCM I-1077. Reprod. Nutr. Dev. 41:57-68.

Chaucheyras-Durand, F., and G. Fonty. 2002. Influence of a probiotic yeast (Saccharomyces cerevisiae CNCM I-1077) on microbial colonization and fermentation in the rumen of newborn lambs. Microb. Ecol. Health Dis. 14:30-36.

Collier, R. J., L. W. Hall, S. Rungruang, and R. B. Zimbleman. 2012. Quantifying heat stress and its impact on metabolism and performance. Pages 74-84 in Proc. 23rd Florida Ruminant Nutrition Symposium, Department of Animal Sciences, University of Florida, Gainesville.

Cray, C., J. Zaias, and N. H. Altman. 2009. Acute phase response in animals: A review. Comp. Med. 59:517-526.

Desnoyers, M., S. Giger-Reverdin, G. Bertin, C. Duvaux-Ponter, and D. Sauvant. 2009. Meta-analysis of the influence of Saccharomyces cerevisiae supplementation on ruminal parameters and milk production of ruminants. J. Dairy Sci. 92:1620-1632.
DeVries, T. J., and E. Chevaux. 2014. Modification of the feeding behavior of dairy cows through live yeast supplementation. J. Dairy Sci. 97:6499-6510.

Dias, A. L. G., J. A. Freitas, B. Micai, R. A. Azevelo, L. F. Greco, and J. E. P. Santos. 2018a. Effect of supplementing yeast culture to diets differing in starch content on performance and feeding behavior of dairy cows. J. Dairy Sci. 101:186-200.

Dias, A. L. G., J. A. Freitas, B. Micai, L. F. Greco, and J. E. P. Santos. 2018b. Effect of supplemental yeast culture and dietary starch content on rumen fermentation and digestion in dairy cows. J. Dairy Sci. 101:201-221.

Dias, J. D. L., R. B. Silva, T. Fernandes, E. F. Barbosa, L. E. C. Graças, R. C. Araujo, R. A. N. Pereira, and M. N. Pereira. 2018c. Yeast culture increased plasma niacin concentration, evaporative heat loss, and feed efficiency of dairy cows in a hot environment. J. Dairy Sci. 101:5924-5936.

Erasmus, L. J., P. M. Botha, and A. Kistner. 1992. Effect of yeast culture supplement on production, rumen fermentation, and duodenal nitrogen flow in dairy cows. J. Dairy Sci. 75:3056-3065.

Ferguson, J. D., T. G. David, and N. Thomsen. 1994. Principal descriptors of body condition score in Holstein cows. J. Dairy Sci. 77:2695-2703.

Ferraretto, L. F., R. D. Shaver, and S. J. Bertics. 2012. Effect of dietary supplementation with live-cell yeast at two dosages on lactation performance, ruminal fermentation, and total-tract nutrient digestibility in dairy cows. J. Dairy Sci. 95:4017-4028.

Gochman, N., and J. M. Schmitz. 1972. Application of a new peroxide indicator reaction to the specific, automated determination of glucose with glucose oxidase. Clin. Chem. 18:943-950.

Gozho, G. N., J. C. Plaizier, D. O. Krause, A. D. Kennedy, and K. M. Wittenberg. 2005. Subacute ruminal acidosis induces ruminal lipopolysaccharide endotoxin release and triggers an inflammatory response. J. Dairy Sci. 88:1399-1403.

Harrison, G. A., R. W. Hemken, K. A. Dawson, R. J. Harmon, and B. K. Barker. 1988. Influence of addition of yeast culture supplement to diets of lactating cows on ruminal fermentation and microbial population. J. Dairy Sci. 71:2967-2975.

Hindrichsen, I. K., M. Kreuzer, J. Madsen, and K. E. Bach Knudsen. 2006. Fiber and lignin analysis in concentrate, forage, and feces: Detergent versus enzymatic-chemical method. J. Dairy Sci. $89: 2168-2176$

Huber, J. T., G. Higginbotham, R. A. Gomez-Alarcon, R. B. Taylor, K. H. Chen, S. C. Chan, and Z. Wu. 1994. Heat stress interactions with protein, supplemental fat, and fungal cultures. J. Dairy Sci. 77:2080-2090

Jiang, Y., I. M. Ogunade, S. Qi, T. J. Hackmann, C. R. Staples, and A. T. Adesogan. 2017. Effects of the dose and viability of Saccharomyces cerevisiae. 1. Diversity of ruminal microbes as analyzed by Illumina MiSeq sequencing and quantitative PCR. J. Dairy Sci. 100:325-342.

Johnson, M. M., and J. P. Peters. 1993. Technical note: An improved method to quantify non-esterified fatty acids in bovine plasma. J. Anim. Sci. 71:753-756.

Jørgensen, E., and A. R. Pedersen. 1998. How to obtain those nasty standard errors from transformed data-And why they should not be used. Biometry Research Unit, Internal Report 7. Danish Institute of Agricultural Sciences, Aarhus, Denmark.

Makimura, S., and N. Suzuki. 1982. Quantitative determination of bovine serum haptoglobin and its elevation in some inflammatory diseases. Nihon Juigaku Zasshi 44:15-21.

Maltz, E., L. F. Barbosa, P. Bueno, L. Scagion, K. Kaniyamattam, L. F. Greco, A. de Vries, and J. E. P. Santos. 2013. Effect of precision feeding on performance, nutrient excretion, and feeding behavior of early lactation dairy cows. J. Dairy Sci. 96:5249-5266.

Marden, J. P., C. Julien, V. Monteils, E. Auclair, R. Moncoulon, and C. Bayourthe. 2008. How does live yeast differ from sodium bicarbonate to stabilize ruminal $\mathrm{pH}$ in high-yielding dairy cows? J. Dairy Sci. 91:3528-3535.

Marsh, W. H., B. Fingerhut, and H. Miller. 1965. Automated and manual direct methods for the determination of blood urea. Clin. Chem. 11:624-627. 
Miller-Webster, T., W. H. Hoover, M. Holt, and J. E. Nocek. 2002. Influence of yeast culture on ruminal microbial metabolism in continuous culture. J. Dairy Sci. 85:2009-2014.

Mishra, M., F. A. Martz, R. W. Stanley, H. D. Johnson, J. R. Campbell, and E. Hilderbrand. 1970. Effect of diet and ambient temperature-humidity on ruminal $\mathrm{pH}$, oxidation reduction potential, ammonia, and lactic acid in lactating cows. J. Anim. Sci. 30:10231028.

Moallem, U., H. Lehrer, L. Livshitz, M. Zachut, and S. Yakoby. 2009. The effects of live yeast supplementation to dairy cows during the hot season on production, feed efficiency, and digestibility. J. Dairy Sci. 92:343-351.

Murata, H., N. Shimada, and M. Yoshioka. 2004. Current research on acute phase proteins in veterinary diagnosis: an overview. Vet. J. $168: 28-40$.

National Research Council. 2001. Nutrient Requirements of Dairy Cattle. 7th rev. ed. Natl. Acad. Press, Washington, DC.

Newbold, C. J., R. J. Wallace, and F. M. McIntosh. 1996. Mode of action of the yeast Saccharomyces cerevisiae as a feed additive for ruminants. Br. J. Nutr. 76:249-261.

Nocek, J. E. 1997. Bovine acidosis: Implications on laminitis. J. Dairy Sci. 80:1005-1028.

Noel, R. J., and L. G. Hambleton. 1976. Collaborative study of a semiautomated method for determination of crude protein in animal feeds. J. Assoc. Off. Anal. Chem. 59:134-140.

Pinloche, E., N. McEwan, J. P. Marden, C. Bayourthe, E. Auclair, and C. J. Newbold. 2013. The effects of a probiotic yeast on the bacterial diversity and population structure in the rumen of cattle. PLoS One 8:e67824.

Plaizier, J. C., D. O. Krause, G. N. Gozho, and B. W. McBride. 2008. Subacute ruminal acidosis in dairy cows: The physiological causes, incidence and consequences. Vet. J. 176:21-31.

Reynolds, C. K., H. F. Tyrrell, and P. J. Reynolds. 1991. Effects of diet forage-to-concentrate ratio and intake on energy metabolism in growing beef heifers: Whole body energy and nitrogen balance and visceral heat production. J. Nutr. 121:994-1003.

Salvati, G. G. S., N. N. Morais Júnior, A. C. S. Melo, R. R. Vilela, F. F. Cardoso, M. Aronovich, R. A. N. Pereira, and M. N. Pereira.
2015. Response of lactating cows to live yeast supplementation during summer. J. Dairy Sci. 98:4062-4073.

Schingoethe, D. J., K. N. Linke, K. F. Kalscheur, A. R. Hippen, D. R. Rennich, and I. Yoon. 2004. Feed efficiency of mid-lactation dairy cows fed yeast culture during summer. J. Dairy Sci. 87:4178-4181.

Schneider, B. H., and W. P. Flatt. 1975. The Evaluation of Feeds Through Digestibility Experiments. University of Georgia Press, Athens.

Sukhija, P. S., and D. L. Palmquist. 1988. Rapid method for determination of total fatty acid content and composition of feedstuffs and feces. J. Agric. Food Chem. 36:1202-1206.

Van Soest, P. J., J. B. Robertson, and B. A. Lewis. 1991. Methods for dietary fiber, neutral detergent fiber and nonstarch polysaccharides in relation to animal nutrition. J. Dairy Sci. 74:3583-3597.

Vidal, B. C. Jr., K. D. Rausch, M. E. Tumbleson, and V. Singh. 2009 Determining corn germ and pericarp residual starch by acid hydrolysis. Cereal Chem. 86:133-135.

Wheelock, J. B., R. P. Rhoads, M. J. VanBaale, S. R. Sanders, and L. H. Baumgard. 2010. Effects of heat stress on energetic metabolism in lactating Holstein cows. J. Dairy Sci. 93:644-655.

Wiedmeier, R. D., M. J. Arambel, and J. L. Walters. 1987. Effect of yeast culture and Aspergillus oryzae fermentation extract on ruminal characteristics and nutrient digestibility. J. Dairy Sci. 70:2063-2068.

Williams, C. H., D. J. David, and O. Lismaa. 1962. The determination of chromic oxide in faeces samples by atomic absorption spectrophotometry. J. Agric. Sci. 59:381-385.

\section{ORCIDS}

M. C. Perdomo (® https://orcid.org/0000-0003-3998-8709

M. G. Favoreto @ https://orcid.org/0000-0003-4869-8922

A. Adesogan (® https://orcid.org/0000-0003-1020-7526

C. R. Staples (1) https://orcid.org/0000-0002-0237-946X

J. E. P. Santos ๑ https://orcid.org/0000-0003-3403-1465 